\title{
The Evaluation of Student's Competencies on Special Education Programs
}

\author{
Safitri $^{1}$, Erna Retna ${ }^{2}$, Zulfiati Syahrial ${ }^{3}$, Diana Nomida Musnir ${ }^{4}$ \\ \{ernaretna_tp14s3@mahasiswa.unj.ac.id $\left.{ }^{2}\right\}$ \\ Universitas Negeri Jakarta, Indonesia ${ }^{1234}$
}

\begin{abstract}
This research was based on the understanding that special education programs are aimed to form learners with physical and or mental disorders to be able to develop attitudes, knowledge and skills as individuals and members of the community in mutual relationships with the surrounding social, cultural and natural environment and to develop skills in the world of occupation or to follow further education. Characteristics of students with special needs also require handling that considers about their potential and needs so that could be improved optimally. This research aimed to evaluate attitudes, knowledge and skills competencies of student in special education programs. The research was conducted by using evaluative qualitative approach with CIPP models of evaluation. The results indicated that mastery of attitude competency in special education programs is quite good, as well as in mastery of knowledge competency. But still need improvement in mastering the skills competency.
\end{abstract}

Keywords: Evaluation, competency, special needs program.

\section{Introduction}

Fundamental distinction between special needs children and normal children lies on their mental characteristics, sensory abilities, communication skills, social behavior and physical characteristics. Therefore, modification in the practice of special education services to develop their capacity. Special characteristics of the students who carried out their educational program at Special Schools are predominant matters that must be considered in carrying out the design, implementation and evaluation of the programs used, so that students are appropriately positioned as the subject of learning rather than a learning object.

Stufflebeam and Shinkfield observed evaluation as a process of obtaining descriptive and evaluative information about the value and usefulness of a matter, either in terms of the purposes, implementation designs and impacts, therefore it may be used as a guideline in decision making processes, needs fulfillment for accountability as well as the escalation of understanding towards the phenomena that occur. ${ }^{1}$ The formulation confirms that the core activity of an evaluation process is providing information on whether the program being evaluated owns the value and the usefulness (worth and merit) and that the information obtained will be taken into consideration in making decisions.

${ }^{1}$ Daniel L. Stufflebeam,,C.F. Madam and T. Kellaghan (eds.), Evaluation Models, Boston : Kluwer Academit Publishers, 2000. pp. xv. 


\section{Research method}

This research is conducted in nine Exceptional junior high school in Garut District. This research used a qualitative approach with CIPP model and designed by comparing the performance of various program dimensions with certain criteria to eventually assign the judgment regarding the weaknesses and strengths of the program being evaluated. Data collection techniques used includes interview techniques, observation, and document review. The instruments used were questionnaires, observation sheets, checklist sheets, and interview guidelines. The data collection technique used in this research refers to the opinion of Creswell who stated that the procedure for collecting data is divided into 4 (four) basic types, namely (1) Observation, (2) Interviews, (3) Documentation, and (4) Field Notes. These four data collection techniques are used, therefore the data are obtained comprehensively. ${ }^{2}$ Data analysis techniques in this research includes qualitative and quantitative descriptive data analysis. The research dataset can be accessed in the https://osf.io/cw69m/ [9].

\section{Findings}

Graduates' competencies are criteria regarding the qualifications of graduates' abilities which includes the attitudes, knowledge, and skills of students which are expected to be achieved after completing their study. Evaluation towards product components is carried out to see the suitability of graduates' competencies with further education with the indicators used, namely students have the appropriate competencies to proceed to the next level.

\subsection{Attitude competencies}

The attitude competencies that must be possessed by the student includes; 1) Possess behavior that reflects the attitude of faith and fear towards God, 2) Possess behavior that reflects a characterized attitude, honesty, and caring, 3) Possess behavior that reflects a responsible attitude, 4) Possess behavior that reflects a true learner's attitude throughout life, 5) Possess behavior that reflects a healthy physical and spiritual attitude, 6) Possess factual knowledge, at a simple, technical as well as specific level, 7) Possess conceptual knowledge at a simple, technical as well as specific level, 8) Possess procedural knowledge at a simple, technical as well as specific level and 9) Possess meta-cognitive knowledge at a simple, technical as well as specific level.

\footnotetext{
${ }^{2}$ John W. Creswell, Research Design, Jakarta : Pustaka Pelajar, 2013. pp. ix.
} 
Table 1. The Evaluation of Graduates' Competencies - Attitude Aspects in Special Education

\begin{tabular}{|c|c|c|c|c|c|c|c|c|}
\hline \multirow{2}{*}{$\begin{array}{l}\text { PNo } \\
\text { r }\end{array}$} & \multirow[t]{2}{*}{ Statement } & \multirow[t]{2}{*}{ Respondents } & \multicolumn{5}{|c|}{ Respondent's Answer } & \multirow[t]{2}{*}{ Result } \\
\hline & & & 1 & 2 & 3 & 4 & 5 & \\
\hline o 1 & Possess behavior that reflects the & 72 & 0 & 0 & 51 & 20 & 1 & 3.3 \\
\hline g & attitude of faith and fear towards & & & & & & & \\
\hline r & God & & & & & & & \\
\hline $\begin{array}{l}\mathrm{a} 2 \\
\mathrm{~m}\end{array}$ & $\begin{array}{l}\text { Possess behavior that reflects a } \\
\text { characterized attitude, honesty, } \\
\text { and caring }\end{array}$ & 72 & 0 & 1 & 55 & 16 & 0 & 3.2 \\
\hline 3 & $\begin{array}{l}\text { Possess behavior that reflects a } \\
\text { responsible attitude }\end{array}$ & 72 & 0 & 3 & 56 & 13 & 0 & 3.1 \\
\hline 4 & $\begin{array}{l}\text { Possess behavior that reflects a } \\
\text { true learner's attitude throughout } \\
\text { life }\end{array}$ & 72 & 0 & 0 & 58 & 10 & 4 & 3.3 \\
\hline 5 & $\begin{array}{l}\text { Possess behavior that reflects a } \\
\text { healthy physical and spiritual } \\
\text { attitude }\end{array}$ & 72 & 0 & 0 & 61 & 10 & 1 & 3.2 \\
\hline 6 & $\begin{array}{l}\text { Possess factual knowledge, at a } \\
\text { simple, technical as well as } \\
\text { specific level }\end{array}$ & 72 & 0 & 7 & 53 & 11 & 1 & 3.1 \\
\hline 7 & $\begin{array}{l}\text { Possess conceptual knowledge at } \\
\text { a simple, technical as well as } \\
\text { specific level }\end{array}$ & 72 & 0 & 28 & 34 & 10 & 0 & 2.8 \\
\hline 8 & $\begin{array}{l}\text { Possess procedural knowledge at } \\
\text { a simple, technical as well as } \\
\text { specific level }\end{array}$ & 72 & 0 & 43 & 18 & 11 & 0 & 2.6 \\
\hline 9 & $\begin{array}{l}\text { Possess meta-cognitive } \\
\text { knowledge at a simple, technical } \\
\text { as well as specific level }\end{array}$ & 72 & 0 & 46 & 17 & 9 & 0 & 2.5 \\
\hline
\end{tabular}

Special education programs is adequately propitious in generating graduates with behaviors that reflect faithfulness and fear towards God with a score of 3.3. The program is also adequately propitious in generating students with behaviors that reflect character, honesty, and care, with a score of 3.2. The program is adequately propitious in generating graduates with behaviors that reflect responsible attitudes, shown with a score of 3.1. The program is adequately propitious in generating graduates with behaviors that reflect the true attitude of learners throughout their lives, indicated with a score of 3.3. The program is also adequately propitious in generating graduates with behaviors that reflect physical and spiritual health, shown with a score of 3.2. The program is adequately propitious in generating graduates with factual knowledge, at a simple, technical as well as specific level, shown with a score of 3.1. Likewise in generating graduates in the these three competencies: 1) Possess conceptual knowledge at a simple, technical as well as specific level, 2) Possess procedural knowledge at a simple, technical as well as specific level, and 3) Possess simple metacognitive knowledge at a technical and specific level. Hence, the special education programs are classified into a fairly good category with the scores of $2.8,2.6$, and 2.5 respectively. 


\subsection{Knowledge competence}

Knowledge competencies that must be possessed by the students include: 1) Having the ability to relate the knowledge possessed in the context of him/herself, 2) Having the ability to relate the knowledge possessed in the context of the family, 3) Having the ability to relate the knowledge possessed in the context of the school, 4) Having the ability to relate the knowledge possessed in the context of society, 5) Having the ability to relate the knowledge possessed in the context of surrounding natural environment, 6) Having the ability to relate the knowledge possessed in the context of the nation and the state and 7) Having the ability to relate the knowledge possessed in the context of the regional area.

Table 2. Evaluation of Graduates' Competencies - Knowledge Aspects in Special Education Programs

\begin{tabular}{|c|c|c|c|c|c|c|c|c|}
\hline \multirow[t]{2}{*}{ No } & \multirow[t]{2}{*}{ Statement } & \multirow[t]{2}{*}{ Respondents } & \multicolumn{5}{|c|}{ Respondent's Answer } & \multirow[t]{2}{*}{ Result } \\
\hline & & & 1 & 2 & 3 & 4 & 5 & \\
\hline 1 & $\begin{array}{l}\text { Having the ability to relate the } \\
\text { knowledge possessed in the } \\
\text { context of him/herself }\end{array}$ & 72 & 0 & 17 & 45 & 8 & 2 & 2.9 \\
\hline 2 & $\begin{array}{l}\text { Having the ability to relate the } \\
\text { knowledge possessed in the } \\
\text { context of the family }\end{array}$ & 72 & 0 & 11 & 54 & 6 & 1 & 3.0 \\
\hline 3 & $\begin{array}{l}\text { Having the ability to relate the } \\
\text { knowledge possessed in the } \\
\text { context of the school }\end{array}$ & 72 & 0 & 32 & 36 & 4 & 0 & 2.6 \\
\hline 4 & $\begin{array}{l}\text { Having the ability to relate the } \\
\text { knowledge possessed in the } \\
\text { context of society }\end{array}$ & 72 & 0 & 41 & 23 & 8 & 0 & 2.5 \\
\hline 5 & $\begin{array}{l}\text { Having the ability to relate the } \\
\text { knowledge possessed in the } \\
\text { context of surrounding natural } \\
\text { environment }\end{array}$ & 72 & 0 & 42 & 22 & 6 & 2 & 2.6 \\
\hline 6 & $\begin{array}{l}\text { Having the ability to relate the } \\
\text { knowledge possessed in the } \\
\text { context of the nation and the } \\
\text { state }\end{array}$ & 72 & 0 & 46 & 22 & 4 & 0 & 2.4 \\
\hline 7 & $\begin{array}{l}\text { Having the ability to relate the } \\
\text { knowledge possessed in the } \\
\text { context of the regional area }\end{array}$ & 72 & 0 & 45 & 23 & 2 & 2 & 2.5 \\
\hline
\end{tabular}

The program is adequately propitious in generating graduates with the ability to relate their knowledge in the context of him/herself, shown with a score of 2.9. The program is said to be adequately propitious in generating graduates with the ability to relate their knowledge in the context of families, shown with a score of 3.0. The program is adequately propitious in generating graduates with the ability to relate their knowledge in the context of school, indicated with a score of 2.6. The program is adequately propitious in generating graduates with the ability to relate their knowledge in the context of the community, shown with a score of 2.5. The program is also said to be adequately propitious in generating graduates with the ability to relate their knowledge in the context of surrounding natural environment, indicated with a score of 2.6. However, the program lacks in generating graduates with the ability to 
relate their knowledge in the context of the nation and state as well as the ability to relate their knowledge in the context of the regional area, shown by the score of 2.4 respectively.

\subsection{Skills competencies}

The skills competencies that must be possessed by the students include: 1) Creative thinking and acting skills through a scientific approach; 2) Productive thinking and acting skills through a scientific approach; 3) Critical thinking and acting skills through a scientific approach; 4) Independent thinking and acting skills through a scientific approach; 5) Collaborative thinking and acting skills through a scientific approach; and 6) Communicative thinking and acting skills through a scientific approach.

Table 3. The Evaluation of Graduates' Competencies - Skills Aspects in Special Education Program

\begin{tabular}{|c|c|c|c|c|c|c|c|c|}
\hline \multirow[t]{2}{*}{ No } & \multirow[t]{2}{*}{ Statement } & \multirow[t]{2}{*}{ Respondents } & \multicolumn{5}{|c|}{$\begin{array}{l}\text { Respondent's } \\
\text { Answer }\end{array}$} & \multirow[t]{2}{*}{ Result } \\
\hline & & & 1 & 2 & 3 & 4 & 5 & \\
\hline 1 & $\begin{array}{l}\text { Creative thinking and acting skills through a } \\
\text { scientific approach }\end{array}$ & 72 & 2 & 44 & 21 & 3 & 2 & 2.4 \\
\hline 2 & $\begin{array}{l}\text { Productive thinking and acting skills through a } \\
\text { scientific approach }\end{array}$ & 72 & 2 & 45 & 21 & 2 & 2 & 2.4 \\
\hline 3 & $\begin{array}{l}\text { Critical thinking and acting skills through a } \\
\text { scientific approach }\end{array}$ & 72 & 2 & 45 & 21 & 2 & 2 & 2.4 \\
\hline 4 & $\begin{array}{l}\text { Independent thinking and acting skills through } \\
\text { a scientific approach }\end{array}$ & 72 & 3 & 46 & 19 & 2 & 2 & 2.3 \\
\hline 5 & $\begin{array}{l}\text { Collaborative thinking and acting skills } \\
\text { through a scientific approach }\end{array}$ & 72 & 3 & 50 & 15 & 2 & 2 & 2.3 \\
\hline 6 & $\begin{array}{l}\text { Communicative thinking and acting skills } \\
\text { through a scientific approach }\end{array}$ & 72 & 3 & 49 & 16 & 4 & 0 & 2.4 \\
\hline
\end{tabular}

The result indicated that the program lacks in generating graduates with creative thinking and acting skills through a scientific approach, shown with a score of 2.4. The program lacks in generating graduates with productive thinking and acting skills through a scientific approach, indicated with a score of 2.4. The program lacks in generating graduates with critical thinking and acting skills through a scientific approach, shown with a score of 2.4. The program lacks in generating graduates with independent thinking and acting skills through a scientific approach, shown with a score of 2.4. The program lacks in generating graduates wwith collaborative thinking and acting skills through a scientific approach, shown with a score of 2.3. The program also lacks in generating graduates with communicative thinking and acting skills through a scientific approach, shown with a score of 2.4.

\section{Discussion}

The results indicated that the domination of graduates' competencies are classified as fairly good, as well as in the domination of knowledge competencies. However, improvement is needed in the domination of skills aspects of the graduates' competencies. In the context of 
special education program, learning achievement indicators prioritize the apective and psychomotor aspects because the objectives of the program tend to be on the independence of students. But in principle, the disclosure of ideal learning outcomes must still reveal the entire changing aspects as a result of the learning process. However, the assessment of the entire realm is a hard thing to do. Therefore, what can be done by educators in this case is merely taking a snapshot of behavior changes that are considered important and are expected to reflect changes that occur as student learning outcomes, either within the dimensions of creativity, taste or intention. ${ }^{3}$

The indicators for each competencies are highly individual, depending on the students' initial abilities. This is not conducted as a form of exclusion, but rather as an adjustment because the educational goals to be achieved by children with special needs are not different from the goals of education in general. This is in accordance with the opinion which stated that goal is not an exclusive goal because it requires certain adjustments to their level of ability. Objectives that are beyond the scope of special needs children, on the other hand, goals that are common for normal children and does not require any special attention, educating special needs children requires special emphasis, for example, detailed formulation. 4

The results of the research which indicated low students' competencies showed that limited intelligence in children with special needs is one of the factors that affects the achievement of skills competencies. However, skills are strongly affected by cognitive mental functions. As stated by Reber who stated that skills are the ability to perform complex patterns of behavior that are neatly arranged and in accordance with the circumstances to achieve certain results. Skills are not merely motor movement but also the manifestation of cognitive mental functions. 5 Thus, the teaching and learning process must be directed in order to be able to develop a class atmosphere that fosters the skills competencies of students. In this case, the educator must assist their students on finding their strengths and weaknesses, hence the program may improve its competence.

\section{Conclusion}

The results of the research also indicated that domination of attitude competencies of graduates in special education programs is classied as fairly good, as well as in the domination of knowledge competencies. On the other hand, improvement is required in dominating the skills competency of graduates.

\section{References}

[1]Daniel L. Stufflebeam,,C.F. Madam and T. Kellaghan (eds.), Evaluation Models, Boston : Kluwer Academit Publishers, pp. xv. (2000)

3 Muhibbin Syah, Educational Psychology with a New Approach, Bandung: Remaja Rosdakarya. 2010, pp. 148.

4 Atmaja, Jati Rinakri, Education and Guidance for Special Needs Children, (Bandung, Remaja Rosdakarya, 2008), pp. 114.

5 Muhibbin Syah, op. cit, pp. 117. 
[2]Robert O. Brinkerhoff, Dale M. Brethower, Terry Hluchyj, Jeri Ridings Nowakowski (auth.), Program Evaluation A Practitioner's Guide for Trainers and Educators, Boston : Kluwer Nijhoff Publishing, pp. (1983)

[3]Jody L. Fitzpatrick, James R. Sanders dan Blaine R. Worthen, Program Evaluation Alternatives Approaches and Practical Guidelines, Boston : Pearson Education, pp. Ix (2004)

[4]John W. Creswell, Research Design, Jakarta : Pustaka Pelajar,. p. ix.(2013)

[5]Sugiono, Educational Research Method, Quantitative, Qualitative, and R\&D, Bandung : Alfabeta,. pp. $338(2010)$

[6]Muhibbin Syah, Educational Psychology with a New Approach, Bandung :Remaja Rosdakarya., pp. $148(2010)$

[7]Atmaja, Jati Rinakri, Education and Guidance for Special Needs Children, Bandung, Remaja Rosdakarya, pp. 114 (2008)

[8]Muhibbin Syah, Educational Psychology with a New Approach, Bandung :Remaja Rosdakarya., pp. 117 (2010) 